\title{
GJB2 Gene
}

National Cancer Institute

\section{Source}

National Cancer Institute. G/B2 Gene. NCI Thesaurus. Code C126999.

This gene plays a role in gap junction function. 